\title{
PENGARUH KENAIKAN SUKU BUNGA BI DAN INFLASI TERHADAP KINERJA KEUANGAN BANK SYARIAH
}

\author{
Universitas Yudharta Pasuruan \\ Dwi Utami Yesika dan Sukamto, ME \\ Sukamto.suminah75@gmail.com
}

\begin{abstract}
Absract: The reality of the increase in world oil prices has prompted the Indonesian government to adopt a policy of increasing the price of fuel oil (BBM) which has caused the Indonesian economy to experience a drastic decline. The increase in fuel prices will be followed by an increase in the price of goods and services. This has caused the inflation rate in Indonesia to decline and further complicate the economic conditions of the people. Since the inflation rate has increased due to the government's policy of raising fuel prices, one of the steps taken by Bank Indonesia to control the inflation rate is to raise interest rates. However, in Islamic law, to avoid operating a bank with an interest system, Islam introduces the principles of muamalat as an alternative to banking in the form of Islamic banking business activities.

The approach used by the author in this study is a quantitative approach with descriptive and regional methods by comparing one variable with another. So the appropriate collection technique is library research is to collect articles, journals, books and so on.

The results showed that there was an influence between the increase in $\mathrm{BI}$ interest rates and inflation on the financial performance of syari'ah banks and there were several factors that influenced the increase in interest rates, among others: the need for funds, competition, government policies, etc. Several factors that influence inflation include: money supply, gross domestic product, exchange rates and interest rates.
\end{abstract}

Keywords: Interest rates, inflation, financial performance, Islamic banking.

\section{A. Pendahuluan}

\section{Latar Belakang}

Dengan adanya kenaikan harga minyak dunia, pemerintah mengambil kebijakan untuk menaikkan harga Bahan Bakar Minyak (BBM) sehingga menyebabkan perubahan perekonomian di Indonnesia mengalami penurun yang drastis. Kenaikan harga BBM akan diikuti oleh kenaikan harga jasa dan barang-barang yang lain di masyarakat. Hal ini menyebabkan tingkat inflasi di Indonesia mengalami penurunan dan semakin mempersulit kondisi ekonomi masyarakat. Inflasi juga merupakan fenomena ekonomi yang selalu menghantui seluruh dunia, karena inflasi sangat berdampak luas pada perekonomian negara terutama pada negara-negara yang baru berkembang seperti Indonesia, dalam hal ini inflasi dapat didefinisikan, Inflasi adalah gejala kenaikan harga-harga barang dan jasa, yang terjadi 
karena permintaan bertambah lebih besar di bandingkan dengan penawaran barang di pasar. ${ }^{1}$ Untuk mengatasi hal tersebut maka pemerintah mengambil langkah-langkah kebijakan untuk menstabilkan kembali kondisi perekonomian yang sempat bergejolak. Kebijakan-kebijakan yang dapat digunakan pemerintah untuk mengatasi inflasi adalah Kebijakan Fiskal, Kebijakan moneter.

Dalam hal ini inflasi juga sangat berhubungan dengan jumlah uang yang beredar di masyarakat. Karena tingkat inflasi mengalami peningkatan akibat kebijakan pemerintah menaikkan harga BBM maka salah satu langkah yang dilakukan oleh Bank Indonesia untuk mengendalikan laju inflasi adalah dengan menaikkan tingkat suku bunga. Suku bunga dapat diartikan harga yang dibayar "peminjam" (debitur) kepada "pihak yang meminjamkan" (kreditur) untuk pemakaian sumber daya secara interval waktu tertentu. Jumlah peminjaman yang diberikan disebut principal, dan harga yang dibayar biasanya diekspresikan sebagai presentase dari principal per unit waktu (umumnya, setahun). ${ }^{2}$ Kebijakan menaikkan atau menurunkan tingkat suku bunga oleh Bank Indonesia ini dikenal dengan istilah politik diskonto yang merupakan salah satu instrumen dari kebijakan moneter. ${ }^{3}$

Namun dalam syariat Islam untuk menghindari pengoperasian bank dengan sistem bunga, Islam memperkenalkan prinsip-prinsip muamalat sebagai alternatif perbankan dalam bentuk kegiatan usaha bank syariah. Sehingga dapat dikatakan bahwa bank syariah adalah sistem perbankan yang sesuai dengan syariat Islam. ${ }^{4}$

Pada kajian ekonomi dan bank Islam, dalam bank syariah dimana pada setiap bank syari'ah menerapkan sistem bagi hasil, sehingga bank syari'ah selamat dari berbagai krisis yang ada di Indonesia. Hal ini disebabkan karena bank syari'ah menggunakan system bagi hasil, penerapan system bagi hasil di bank syari'ah, membuat bank syari'ah lebih tangguh dan tahan dari gejolak moneter, baik dalam maupun luar negeri. Dalam hal ini bank syari'ah tidak dibebani membayar bunga simpanan nasabah. Bank syari'ah hanya membayar bagi hasil yang jumlahnya sesuai dengan tingkat keuntungan perbankan syari'ah. Dengan system bagi hasil tersebut bank syari'ah selamat dari negative spread.

Dengan demikian, adanya kenaikan tingkat suku bunga pada bankbank umum baik langsung maupun tidak langsung akan membawa dampak terhadap kinerja bank syariah. Karena kinerja bank merupakan salah satu dasar penilaian terhadap kemampuan bank dalam menjalankan fungsinya sebagai penghim pun dan pengelola dana bagi masyarakat, perbiakan kondisi kinerja keuangan perbankan nasional membawa kepada suatu alam persaingan yang ketat pada bank-bank umum dari suatu periode keperiode berikutnya. Sehingga dengan naiknya tingkat suku bunga maka akan diikuti oleh naiknya suku bunga simpanan dan suku bunga pinjaman pada bank konvensional. Sehingga orang akan cenderung untuk menyimpan dananya di

\footnotetext{
${ }^{1}$ Nurul Huda, Ekonomi Makro Islam:Pendekatan Teoritis (Jakarta: Kencana, 2009), 175

${ }^{2}$.Fahmi Ihram, Manajemen Perbankan: Konvensional dan Syariah (Jakarta:Mitra Wacana Media,2015), 219

${ }^{3}$ Ibid. 205

${ }^{4}$.www.bi.go.id, http://www.bi.go.id/id/moneter/bi-rate/data/Default.
} 
bank konvensional dari pada di bank syariah karena bunga simpanan di bank konvensional naik yang pada akhirnya tingkat pengembalian yang akan diperoleh oleh nasabah penyimpan dana akan mengalami peningkatan.

Kenaikan tingkat suku bunga inilah yang menjadi dilema dunia perbankan syariah saat ini, karena dikhawatirkan akan ada perpindahan dana dari bank syariah ke bank konvensional. Tetapi ada juga keuntungan yang diperoleh bank syariah dengan naiknya suku bunga yakni permohonan pembiayaan (kredit) di bank syari'ah oleh nasabah diperkirakan akan mengalami peningkatan seiring dengan naiknya bunga pinjaman pada bank konvensional atau bank umum. Berdasarkan paparan diatas, bahwa suku bunga dan inflasi sangat berpengaruh terhadap perekonomian dan kinerja keuangan suatu bank, namun pada bank-bank syari'ah mereka menggunakan system bagi hasil, apakah dengan adanya kenaikan suku bunga dan inflasi kinerja keuangan suatu bank syari'ah akan berpengaruh, dimana pada syari'ah Islam dikemukakan bahwa bunga sama dengan riba, sedangkan riba pada bank syari'ah diharamkan.

\section{B. PEMBAHASAN}

\section{Kajian Suku bunga}

\section{a. Pengertian Suku Bunga}

Suku bunga adalah harga yang dibayar "peminjam" (debitur) kepada "pihak yang meminjamkan" (kreditur) untuk pemakaian sumber daya secara interval waktu tertentu. Jumlah peminjaman yang diberikan disebut principal, dan harga yang dibayar biasanya diekspresikan sebagai presentase dari principal per unit waktu (umumnya, setahun).

Suku bunga yang menyediakan jangkar bagi suku bunga- suku bunga yang lain, yaitu suku bunga riil jangka pendek yang bebas risiko. Yang dimaksud dengan suku bunga riil adalah suku bunga yang akan berlakau dalam perekonomian jika harga rata- rata barang dan jasa diperkirakan tetap kostan selama usia peminjaman. Yang dimaksud denagn suku bunga bebas risiko adalah suku bunga pinjaman dimana peminjamnya tidaka akan gagal memenuhi kewajiban apapun.

Yang dimaksud jangka pendek adalah suku bunga dari pinjaman yang akan jatuh tempo dalam setahun. Semua suku bunga yang lain berbeda dengan suku bunga yang ini sesuai aspek- aspek tertentu dari pinjaman, seperti jangka waktu jatuh tempo atau default risk-nya, atau karena adanya inflasi.

b.Bunga Nominal atau Real

Ditegaskan bahwa dalam sebuah ekonomi inflasioner rata-rata bunga yang akan mengoreksi kerugian yangdialami oleh kreditor yang disebabkan inflasi bisa dibenarakan dengan cara indeksasi pinjaman, yaitu, dengan membolehkan tambahan untuk dijadikan kompensasi bagi kerugian dari kekuatan uang. Untuk mendukung argument ini, para permarkarsa pandangan ini, seperti sarjana kontemporer Syauqi Dunya (1985), mengajukan beberapa pandangan yang berkaitan dengan pembahasan mereka tentang kontrak-kontrak pinjaman.

Seperti dibahas dalam kitab fiqih, hutang dalam pinjaman bisa berupa barang atau uang. Jika pinjaman ini berupa barang, biasanya para ahli 
hukum mengemukakan pandangannnya bahwa debitur harus membayar kembali dengan barang yang sama (misalnya satu kilo daging dengan stu kilo daging) sejauh terdapat barang yang sama.

Sebaliknya, jika nilainya telah berubah sejak kontrak pinjaman dimasukkan maka nilainya disesuaikan. Perbedaan pendapat muncul ketika nilai barang berubah. Jika perubahan itu adalah akibat dari kerusakan dari barang itu, kemudian kebanyakan para ahli hukum mengambil pandangan bahwa nilai awal dari barang itu yang harus di kembalikan. Jika perubahan itu dalam nilai disebabkan karena perubahan temapat (seperti Negara atau kota), pandangan mayoritas adalah bahwa nilai dari obyek hutang terjadi seharusnya dibayar dan bukan dengan barang yang sama. Jika perubahan itu disebabkan oleh waktu, yaitu sebagai akibat dari perubahan harga, beberapa diantara mereka mengatakan bahwa dibayar dengan barang yang sama, sementara yang lain mengatakan bahwa nilai awal dari barang itu yang seharusnya diberikan. 5

Ketika hutang itu berupa uang, dan nilainya berubah, beberapa ahli hukum mengambil pandangan bahwa meskipun nilainya berubah, kriditor harus menerima jumlah awal dalam pembayaran hutang.6 Pandanganpandangan ini mengarahkan kepada kesimpulan bahwa tidak ada kesempatan mengenai apakah dalam situasi inflasi atau deflasi, nilai uang yang sama yang dibayarkan dalam pembayaran hutang.

Para pengkritik argumentasi ini atas beberapa dasar, dengan mempertahankan bahwa setiap penambahan akan bertentangan dengan perintah al-Quran untuk menerima hanya uang pokok, dinyatakan dalam pengertian keuangan. Lebih sulit adalah persoalan mengetahui dengan pasti kurs yang harus diterapkan untuk kompensasi bagi kerugian yang timbul karena inflasi. Karena banyak indeks yang menjadi ukuran daya beli uang, seperti indeks harga beli konsumen dan indeks harga seluruh penjualan, semua itu akibat dari beberapa kekurangan, maka sulit untuk harga kurs universal yang dapat digunakan untuk indeksasi.7

3. Pandangan neo-Revivalis Tentang Riba dan bunga

Pandangan neo-Revivalis ini adalah sesuatu yang dominan tentang perdebatan kontemporer. Pandangan ini menekankan bentuk legal dari riba sebagai mana diungkapkan dalam hukum islam, dan menegaskan bahwa pernyataan yang ditetapkan dalam al-Qur'an harus diambil makna harfiahnya, tanpa memperhatikan apa yang dipraktekkan di dalam periode al islam. Menurut pandangan ini, karena al-Qur'an telah menyatakan bahwa hanya uang pokok yang diambil, maka tidak ada pilihan kecuali menafsirkan riba sesuai dengan pernyataan itu. Oleh karena itu, keberadaan ketidak adilan atau sebaliknya didalam sebuah transaksi pinjaman tidak relevan. Apa pun keadaannya, pemberi pinjaman tidak mempunyi hak untuk menerima tambahan atas dan melebihi uang pokok. 8

\footnotetext{
${ }^{5}$ Muhammad Abdullah, Al-ribafi Nazar Al-Qanun Al Islami, (Cairo: IAIB,tt), 5-8.

6 .Lihat dalam Dunya Shawq. Taqallubat al-Quwwal al-Syira'iyya li al-Nuqud,(al bunuq alislaamiyyah(43).1985) 39-45,

7 M.Umer Chapra,Towards a Just Monetary System ( London Leicester: Islamic Foundasion.1985) 3942.

${ }^{8}$ Muhamad Abu Zahra, Bahuth fi al-Riba (Kuwait: Dar al-Buhuth al-Ilmiyya.1970), 142
} 
Meskipun neo-Revivalis Mawdudi9 dan Sayyid Qutb10 membahas lebih jauh persoalan ketidak adilan dalam riba, secara umm mereka tidak menyatakan bahwa ketidak adilan itu adalah rasion d'etre dari larangan itu. Menurut Mawdudi, maksud bahwa zhulm (ketidakadilan) itu merupakan alasan mengapa bunga atas pinjaman itu tidak dibolehkan dan dari sini traksaksi bunga semacam ini berlangsung karena tidak menyebabkan kekejaman kemudian dibolehkan, masih belum digantikan.11

Dengan mengikuti jalan pemikiran ini, para penulis neo-Revivalis menafsirkan riba dengan cara tidak membolehkan setiap tambahan dalam pinjaman. Mawdudi mendefinisikan riba dengan "jumlah yang diterima oleh pemberi pinjaman dari penerima pinjaman dengan angka bunga yang pasti.12 Barang kali salah satu dokumen yang penting tentang perbankan islam, laporan CII (Council Islamic Ideologi) lebih eksplisit: Tidak ada kebetulan suara sepenuhnya diantara berbagai mazhab pemikiran didalam islam bahwa istilah riba menunjukkan pada bunga dalam semua tipe dan bentuknya.13 Capra mengatakan bahwa riba mempunyai makna yang sama dengan bunga.14 Bagi para pakar Ekonomi Islam ini, larangan riba, yang ditafsirkan dengan bunga, adalah aksiomatik. Muhamad Uzair, seorang teoritis Perbankan Islam, menegaskan bahwa bunga dalam semua bentuknya adalah sama dengan riba, dan mengklaim adanya kesepakatan atas persoalan ini:

Tapi persoalannya, apakah penafsiran tentang riba itu banar? karena tidak bermaksud bahwa setiap penambahan atas dan melebihi uang pokok adalah riba sesuai dengan keadan pinjaman atau hutang. Diantara alasan yang dikemukakan untuk pembenaran pengambilan bunga adalah alasan abstinence.15

Pelopor teori ini menegaskan bahwa ketika kreditur menahan diri (abstinence), ia menangguhkan keinginannya memanfaatkan uangnya sendiri semata-mata untuk memenuhi keinginan orang lain. la meminjamkan modal yang semestinya dapat mendatangkan keuntungan bagi dirinya sendiri. Jika peminjam menggunakan uang itu untuk memenuhi keinginan pribadi, ia dianggap wajib membayar sewa terhadap sebuah rumah, perabotan, maupun kendaraan.

Benarkah bunga merupakan imbalan karena menahan diri? kenyataannya, kreditor akan meminjamkan uang yang tidak ia gunakan sendiri. Kreditor hanya akan meminjamkan uang berlebih dari yang ia pergunakan. Dengan demikian, sebenarnya kreditor tidak menahan diri atas

\footnotetext{
${ }^{9}$ Abu al-A'la Mawdudi,. Al-Hadarat al-Islamiyya. Al-Riba trans. Muhammad 'Asim al-hadad(Beirut: Dar al-Fikr.n.d.1970), 213

${ }^{10}$ Sayyid Qutb, Fi zilal al-Qu'an. Tafsir Ayat al-Riba. (Beirut: Dar al-Buhut al-'Ilmiyya.1961), 241.

${ }^{11}$ Abu al-A'la Mawdudi. Prohibitionof Inters in Islam. (Islamabad: Al-Islam, 1986).6-8

${ }^{12}$ Abu al-A'la Mawdudi,, Towards Understanding Islam the Qur'an ,Trans. Zafar Ishaq Ansari (Leicester:Islamic Foundasion.1988), 125.

${ }^{13} \mathrm{CII}$ ( Council of Islamic Ideology). Consolidated Recommendation on the Islamic Economic system. ( Islamadad: Council of Islamic Ideology.1983).7

${ }^{14}$ M Umer Capra, Towards a Just Monetary System (London Leicester: Islamic Foundasion. 1985), 57

${ }^{15}$ Sa'ad A.S.Harran, Islamic Finance Partnership Financing (Kuala Lumpur: Pelanduk Publikation, 1983), 123
} 
apa pun. Tentu ia tidak boleh menuntut imbalan atas hal yang dilakukannya tersebut.

Disamping itu, tidak ada standar yang dapat digunakan untuk mengukur unsur penundaan konsumsi dari teori bunga abstinence. Kalaupun ada, bagaimana menentukan suku bunga yang adil antara kedua belah pihak, yakni pemilik uang dan penggunaan uang tersebut?

Dalam tinjauan syari'ah, unsur penundaan konsumsi ataupun penundaan investasi tidak dapat di jadikan illat dalam penetapan hukum. Para ulama' merumuskan, " salah satu syarat illat hukum (argumentasi hukum) adalah sifat yang jelas, zahit, tetap/konsisten. Feeling seorang yang menunggu dan melakukan tindakan abstinence itu sangat berbeda-beda. ${ }^{16}$

4. Al-Qur'an Tentang Bunga

Di masa awal munculnya islam, bnga telah ada didalam masyarakat Arab baik dalam transaksi pinjaman uang maupun transaksi barter komonditas. Oleh karena bunga itu mengakar dalam-dalam di dalam kehidupan ekonomi masyarakat, maka dalam melarang bunga pun Al-Qur'an diwahyukan secara berangsur-angsur, sebagaimana pelarangan minuman keras, sehingga kehidupan ekonomi masyarakat tidak mendadak kacau. Berikut ini adalah ayat-ayat Al-Qur'an yang berhubungan dengan bunga:

1. Orang-orang yang makan (mengambil) riba tidak dapat berdiri melainkan seperti berdirinya orang yang kemasukan setan lantaran (tekanan) penyakit gila. Keadaan meraka yang demikian itu, adalah disebabkan mereka berkata (berpendapat bahwa) sesungguhnya jual beli itu sama dengan riba. Padahal Allah telah menghalalkan jual beli dan mengharamkan riba. Orang-orang yang telah sampai kepadanya larangan dari tuhannya, lalu terus berhenti (dari mengambil riba), maka baginya apa telah diambilnya dahulu. (sebelum dating larangan); dan urusannya (terserah) kepada Allah. Orang yang kembali (mengambil riba), maka orang itu adalah di penghuni-penghuni neraka; mereka kekal di dalamnya. Allah memusnahkan Riba dan menyuburkan sedekah. Dan Allah tidak menyukai setiap orang yang tetap dalam kekafiran, dan selalu berbuat dosa. (QS.al-Baqarah : 275-276)

2. Hai orang-orang yang beriman, bertakwalah kepada Allah dan tinggalkan sisa riba (yang belum dipungut) jika kamu orang-orang yang beriman. Maka, jika kamu tidak mengerjakan (yaitu meninggalkan sisa riba) maka bagimu pokok hartamu; kamu tidak menganiaya dan tidak (pula) dianiaya. (QS.al-Baqarah : 278-279)

3. Hai orang-orang yang beriman, janganlah kamu memakan riba dengan berlipat ganda dan bertakwalah kamu kepada Allah supaya kamu mendapat keberuntungan. (QS. Ali 'Imran :130)

Urutkan waktu diturutkan yat-ayat tersebut secara berangsur-angsur melarang bunga. Ayat-ayat pertama dalam al-Qur'an (Ar-Rum, 39) diturunknnya mengenai bunga yang dibandingkan dengan zakat. Disitu dinyatakan bahwa bunga tidak menambah harta manusia, malah sebaliknya, yaitu menguragi, sementara zakat meninggalkannya secara berlipat-lipat.

\footnotetext{
${ }^{16}$ Wahbah az-Zuhaily, Usul Fiqh al-Islami (Beirut: Darul-Fikr, 1985), 231.
} 
4. Dalam ayat berikutnya (Ali 'Imran :130), kaum mukminin diberitahu agar tidak makan bunga-berbunga yang berlipat hingga dua atau bahkan empat kali asal jumlah pinjaman. Dalam ayat berikutnya (an-Nisaa' : 160161), kaum muslimin diingatkan untuk mematuhi perintah al-Qur'an mengenai pelarangan bunga agar mereka tidak usah merasakan derita kaum Yahudi yang melanggar larangan bunga dan akan menerima siksa yang pedih. Akhirnya turunlah wahyu terakhir (ayat-ayat 275,276,278, dan 279 dari surat al-Baqarah) yang melarang bunga. Ayat-ayat ini membedakan antara perdagangan (ba'i) dan buga (riba). Ayat itu mengutuk bunga berikut pemakannya dan memuji keberkahan sedekah. Ayat tersebut secara mutlak melarang pemungutan bunga dan memerintahkan kaum mukminin untuk menghentikan serta menerima pengambilan hanya modal pokoknya saja. Akhirnya, ayat tersebut mengingatkan mereka untuk memerhatikan perang dari Allah da Rasullah jika mereka tetap melanggar aturan dan kembali makan bunga. ${ }^{17}$

5. Hadis-Hadis Nabi Muhamad SAW Tentang Bunga

Didalam bagian ini mengutip beberapa Hadis Nabi dan kaum Muslimin yang menunjukkan bahwa Beliau tidak hanya mengutuk riba (bunga) dengan kata-kata yang barangkali paling keras, melainkan juga menunjukkan bahwa riba itu terdapat baik dalam transaksi uang maupun komonditas. Dengan kalimat yang amat jelas Hadis tersebut menambahkan pemahaman kita mengenai konsep Islam tentang riba dan menjadikan kita lebih terfokus, sebagai petunjuk kita. Hadis tersebut yaitu:

1. Abu Sa'id al-Khudri meriwayatkan bahwa Rasullah SAW bersabda: “ Emas untuk emas, perak untuk perak, gandum untuk gandum, bur untuk bur, kurma untuk kurma, garam untuk garam, sama setara dan tunai. Barang siapa memberi atau mengambil lebih, maka baik pemberi maupun pengambil sama-sama mengambil riba". (Muslim)

2. Abu Sa'id al-Khudri meriwayatkan bahwa Rasullah SAW ber sabda: "Jangan menjual emas dengan emas kecuali sama setara dan jangan menaikkan sesuatu dari padanya atas sesuatu, dan jangan menjual perak dengan perak kecuali sama setara dan jangan menaikkan sesuatu dari padanya atas sesuatu, dan janganlah menukar (barang) yang ada dengan barang yang tidak ada”. Muttafaq'alaih. Di dalam satu riwayat disebutkan: Jangan menukar emas dengan emas, perak dengan perak, kecuali sama setara." (Bukhari dan Muslim).

3. Ibnu Mas'ud meriwayatkan bahwa Rasullah Saw bersabda: "Walau riba meningkatkan harta, pada akhirnya ia akan mengarah kepada pengurangan." (Ibnu Majah)

Sekian banyak hadis tentang riba itu semua masih belum seluruhnya. Namun dari serangkaian hadis yang dipaparkan diatas, paling tidak kita dapati tiga kesimpulan utama, (pertama), barter tidak disukai, karena berpotensi mengandung riba. (kedua), riba atau bunga itu lebih jahat daripada perzina'an. (ketiga), Nabi SAW telah dengan tegas menghapus bunga dalam sistem ekonomi islam, dan hanya bukan makan bunga saja yang diharamkan, melainkan segala sesuatu yang

17 .Muhammad Sharif, Sistem Ekonomi Islam: Prinsip Dasar (Jakarta: Kencana Prenada Media Group, 2012), 215 
berhubungan dengan bunga juga haram, seperti membayar bunga, menuliskannya, dan menjadi saksinya. ${ }^{18}$

6. Mengapa Bunga di Larang?

Tentang alasan dilarangnya bunga, terdapat beberapa pandangan yang saling berbeda. Namun paling tidak sepakat mengenai satu hal yakni bahwa pelarangan bunga tersebut adalah karena alasan adanya bahaya moral, sosial, dan ekonomi didalam bunga.

Beberapa akibat mengenai tentang bunga sehingga bunga itu dilarang :

Pertama, riba atau bunga menanamkan rasa kikir, mementingkan diri sendiri, tak berperasaan, tak perduli, kejam, rakus, dan penyembahan kepada harta. Bunga menghancurkan semangat simpati, sling tolong dan kerja sama, serta mengaruhi rasa kasih saying, persaudaraan dan persatuan di dalam masyarakat. Kita lihat disekeliling kita para pemakan bunga biasanya kikir, mementingkan diri sendiri, berhati keras, yang mengeksploitasi kepapaan kaum miskin serta memeras tenaga mereka tanpa ada penyesalan moral terhadap penderitaan para pengutang.

Kedua, bunga mengembangbiakkan kemalasan dan menimbulkan pendapatan tanpa bekerja. Bukannya menangani usaha bisnis dan menggunsksn keliheian, kecakapan, pengetahuan berbisnis, orang yang memiliki uang malah meminjamkannya demi bunga dan dengan demikian lalu hidup seperti parasit. Biasanya, uang yang didapat dengan mudah seperti itu dihamburkan dengan hal-hal yang idak baik seperti judi, pacuan kuda, pertaruhan, minum, dan zina, atau belanja barang mewah, pest pernikahan dan pesta pora lainnya.

Ketiga, bunga juga menimblkan kejahatah ekonomi. la mendorong orang melakukan penimbunan uang, sehingga memengaruhi peredarannya diantara sebagian besar anggota masyarakat. la juga menyebabkan timbulnya monopoli, kartel srta konsentrasi kekayaan di tangan sedikit orang. Dengan demikian, distribusi kekayaan didalam masyarakat menjadi tidak merata dan celah antara sikaya dan simiskin pun melebar. Masyarakatpun dengan tajam tebagi menjadi dua kelompok yaitu kaya dan miskin yang pertentangan kepentingan mereka memengaruhi kedamaian dan harmoni didalam masyarakat. Lebih lagi, karena bunga pula maka distori ekonomi seperti resensi, inflasi dan pengangguran terjadi.

Keempat, investasi modal terhalang dariperusahaan-perusahaan yang tidak mampu menghasilkan laba yang sama atau lebih tinggi dari suku bunga yang sedang bejalan, sekalipun proyek ditangani oleh perusahaan itu amat penting bagi Negara dan bangsa. Semua aliran sumber-sumber finansial didalam Negara bebelok ke-arah perusahaanperusahaan yang memiliki prospek laba yang sama atau lebih tinggi dari pada suku bunga yang sedang berjalan, sekalipun perusahaan tersebut tidak atau sedikit saja memiliki nilai social.

Kelima, bunga yang dipungut pada utang internasional malah lebih bruk lagi karena memperparah DSR( debt-service ratio) Negara-negara

18. Ibid. 218 
debitur. Bunga itu hanya menghali pembangunan ekonomi negara-negara miskin, melainkan juga menimbulkan transfer sumber daya dari Negara miskin kenegara kaya. Lebih dari itu, ia juga memengruhi hubungan antara Negara miskin dan kaya sehingga membahayakan keamanan dan perdamaian internasional. ${ }^{19}$

\section{Kajian Inflasi}

a. Pengertian Inflasi

Inflasi didefinisikan sebagai kecenderungan dari harga-harga untuk menaik secara umum dan terus menerus. Kenaikan harga dari satu atau dua macam barang saja tidak dapat dikatakan sebagai inflasi kecuali kenaikan tersebut membawa dampak terhadap kenaikan harga sebagian besar barang-barang lain. Secara garis besar ada tiga kelompok teori inflasi, masing-masing teori ini menyatakan aspek-aspek tertentu dari proses inflasi dan masing-masing bukan teori inflasi yang lengkap yang mencakup semua aspek penting dari proses kenaikan harga.

Ketiga teori itu adalah : teori kuantitas, teori Keynes, dan teori strukturalis.

Teori kuantitas uang adalah teori yang paling tua mengenai inflasi, namun teori ini masih sangat berguna untuk menerangkan proses inflasi pada saat ini terutama di negara sedang berkembang. Teori ini menyoroti peranan penambahan jumlah uang beredar dan harapan masyarakat mengenai kenaikan harga. Intinya adalah sebagai berikut :

1) Inflasi hanya biasa terjadi kalau ada penambahan jumlah uang beredar.

2) Dengan bertambahnya uang beredar secara terus menerus, masyarakat akan merasa kaya sehingga akan menaikkan konsumsinya, dan keadaan ini akan menaikkan harga.

3) Laju inflasi ditentukan oleh laju pertambahan jumlah uang yang beredar dan oleh harapan masyarakat mengenai kenaikan harga di masa yang akan datang.

Menurut Keynes, inflasi terjadi karena masyarakat menginginkan barang dan jasa yang lebih besar daripada yang mampu disediakan oleh masyarakat itu sendiri.

Proses inflasi menurut kelompok ini adalah proses perebutan bagian rejeki diantara kelompok-kelompok sosial yang menginginkan bagian yang lebih besar dari apa yang mampu disediakan oleh masyarakat. Hal ini menimbulkan inflationarygap karena permintaan total melebihi jumlah barang yang tersedia.

Teori Strukturalis memberikan titik tekan pada ketegaran atau infleksibilitas dari struktur perekonomian negara-negara berkembang. Faktor strukturalis inilah yang menyebabkan perekonomian negara sedang berkembang berjalan sangat lambat dalam jangka panjang. Teori ini disebut inflasi jangka panjang. Menurut teori ini ada dua faktor utama yang dapat menimbulkan inflasi .

(1). Pertama, ketidak elastisan penerimaan ekspor, yaitu pertumbuhan nilai ekspor yang lamban dibanding dengan pertumbuhan sector-

${ }^{19}$. Ibid. 234 
sektor lain. Hal ini disebabkan dua faktor utama yaitu : Jenis barang ekspor yang kurang responsif terhadap kenaikan harga dan nilai tukar barang ekspor yang semakin memburuk.

(2). Kedua, ketidak elastisan produksi bahan makanan di dalam negeri.

Dalam hal ini laju pertumbuhan bahan makanan di dalam negeri tidak secepat laju pertumbuhan penduduk dan laju pendapatan perkapita.

Akibat dari ini terjadi kenaikan harga barang lainnya.

Karena inflasi berpengaruhi terhadap tingkat investasi, maka aktivitas perdagangan di bursa saham akan terpengaruhi. Aktifitas perdagangan saham akan mempengaruhi kemungkinan perolehan keuntungan. Dengan demikian inflasi berpengaruh terhadap aktifitas di pasar saham. ${ }^{20}$

2. Inflasi

Inflasi secara umum sering dipahami sebagai meningkatkannya harga barang secara keseluruhan. Dengan demikian, terjadi penurunan daya beli uang atau decreasing purchasing power of money. Oleh karena itu, menurut paham ini, pengambilan bunga uang sangatlah logis sebagai kompensasi penurunan daya beli uang selama dipinjamkan. ${ }^{21}$

Argumen tersebut memang sangat tepat seandainya dalam dunia ekonomi yang terjadi hanyalah inflasi saja tanpa deflasi atau stabil.

Demikian juga, kita tidak boleh menutup kemungkinan bahwa dalam transaksi muamalah syari'ah seperti ba'i al-murobahah, ba'i as-salam, musyarokah, dan mudharabah terdapat keuntungan. Tidak jarang keuntungan yang dihasilkan dari transaksi-transaksi tersebut memiliki nilai return yang melebihi tingkat inflasi.

Lebih lanjut, Islam memberikan dorongan untuk melakukan isvestasi dengan jumlah yang lebih besar dan yang lebih banyak dari motivasi konvensional. Kalau secara konvensional terdapat motif profit-taking dan inflasi, dalam syari'ah Islam disamping dua hal tersebut ditambah lagi dengan adanya kewajiban zakat dan larangan mendiamkan asset.

3. Jenis inflasi menurut sifatnya

Laju inflasi dapat berbeda antara satu negara dengan negara yang lain atau dalam satu negara untuk waktu yang berbeda. Atas dasar besarnya laju inflasi, inflasi dibagi dalam dua kategori :

a. Inflasi merayap ( inflasi rendah )

Inflasi ini ditandai dengan laju inflasi yang rendah ( kurang dari 10\% per tahun). Kenaikan harga berjalan secara lambat, dengan persentase yang kecil serta dalam jangka yang relatip lama.

b. Inflasi menengah

Inflasi ini ditandai dengan kenaikan harga yang cukup besar (biasanya double digit atau bahkan triple digit). Dan kadang kala berjalan dalam waktu yang relatif pendek serta mempunyai sifat akselerasi. Artinya, harga-harga minggu atau bulan ini lebih tinggi dari minggu atau bulan

\footnotetext{
20. www.bi.go.id dan Fahmi Ihram, Manajemen Perbankan: Konvensional dan Syariah (Jakarta:Mitra Wacana Media, 2015), 120

21. Dawam Raharjo, The Question of Islamic Banking in Indosesia. Dalam Mohamed Aril (ed), Islamic Banking In Sout East Asia (Singapura:ISEAS, 1988), 45.
} 
lalu dan seterusnya. Efeknya terhadap perekonomian lebih berat dari pada inflasi merayap.

c. Inflasi Tinggi

Merupakan inflasi yang paling parah akibatnya. Harga naik sampai lima atau enam kali lipat. Masyarakat tidak lagi berkeinginan untuk menyimpan uang. Nilai merosot tajam sehingga ingin ditukarkan dengan barang. Perputaran uang makin cepat, harga naik secara akselarasi. Biasanya keadaan ini timbul apabila pemerintah mengalami deficit anggaran belanja ( misalnya ditimbulkan oleh adanya perang) yang dibelanjai/ditutup dengan mencetak uang.

3.Analisa Pengaruh Kenaikan Suku Bunga BI dan Inflasi Terhadap Kinerja Keuangan Bank Syari'ah

Kinerja keuangan adalah suatu analisis yang dilakukan untuk melihat sejauh mana perusahaan telah melaksanakan dengan menggunakan aturan-aturan pelaksanaan keuangan secara baik dan benar. Seperti dengan membuat suatu laporan keuangan yang telah memenuhi standar dan ketentuan dalam SAK (Standar Akuntansi Keuangan) dan lainnya. Dalam suatu bank kinerja keuangannya selalu dipengaruhi oleh kenaikan inflasi dan suku bunga, dimana setiap negara apabila mengalami kenaikkan inflasi maka pemerintah untuk mengurangi gejolak inflasi tersebut menggunakan alternatif yaitu dengan menaikkan suku bunga. Pada bank konvensional dengan adanya kenaikan suku bunga tersebut pasti bank tersebut akan ikut menaikkan suku bunga sesuai dengan ketetapan pemerintah. Namun dalam bank bank syari'ah, kenaikan suku bunga apakah akan berpengaruh terhadap kinerjan keungannya, yang mana bank syari'ah tidak menggunakan sistem bunga dalam pembagian keuntungan, tapi bank syari'aah menggunakan sistem bagi hasil.

\section{Tabel 1.}

Analisis Suku Bunga BI Dan Inflasi Terhadap Kinerja Keuangan Bank Syari'ah Dilihat Dari Output Coefficient

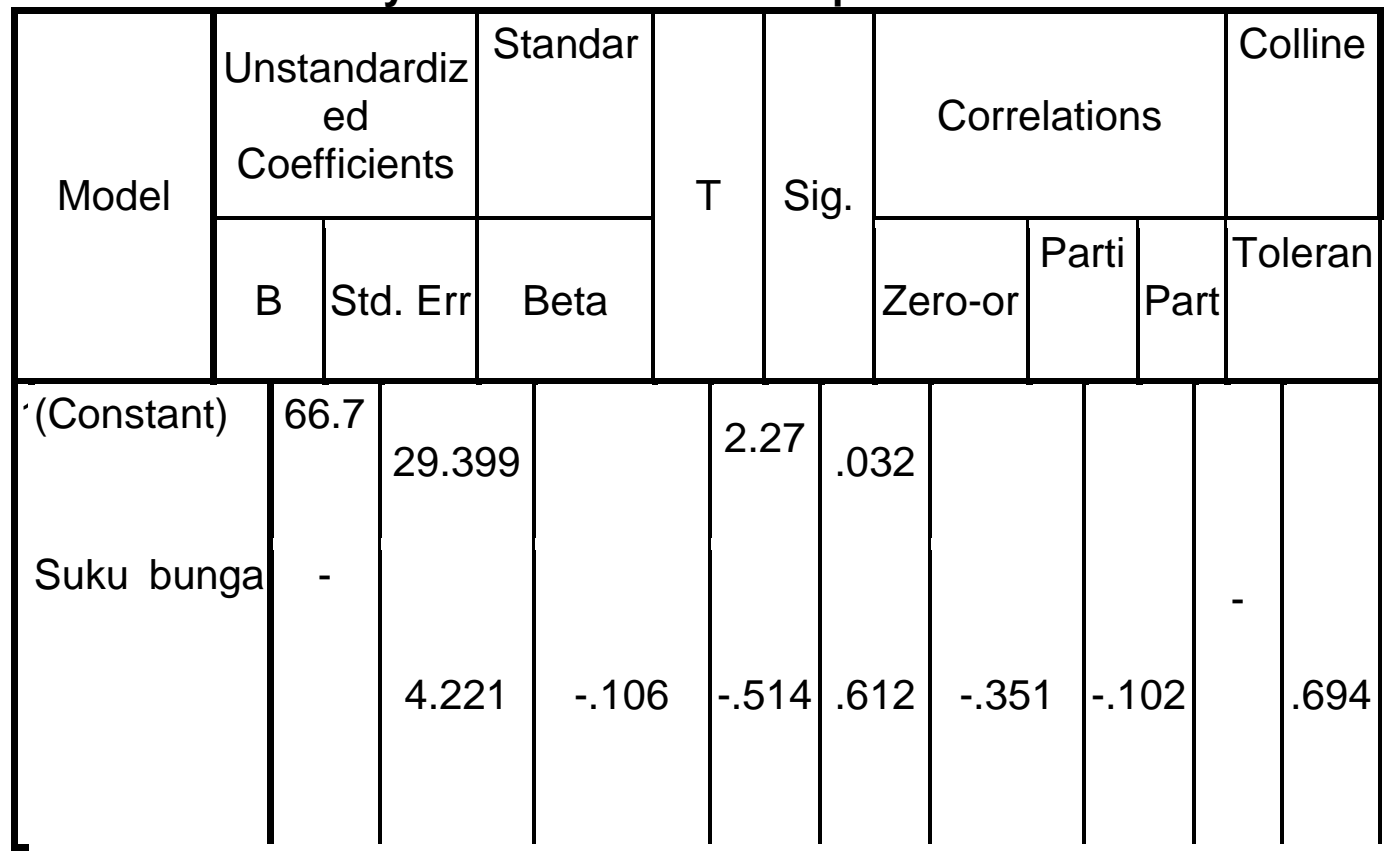




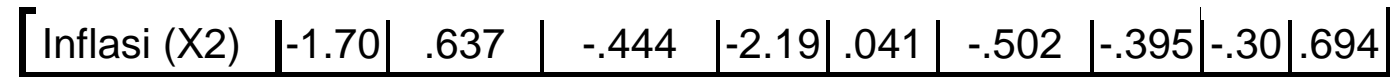

a. Dependent Variable: Kinerja

keuangan bank

(Y)

$Y=\alpha+\beta 1 . X 1+\beta 2 \cdot X 2+\varepsilon$

$Y=66,779+(0,106 .-2,169)+(-0,444 .-1,370)+29,399$

$\mathrm{Y}=66,779+-0,229914+0,60828+29,399$

$$
=96,556366
$$

Dengan keterangan:

$\mathrm{Y}=$ Nilai kinerja keuangan

$\alpha=$ Nilai $Y$ bila semua bernilai 0

$\beta 1=$ Koefisien variabel $X 1$

$\beta 2=$ Koefisien variabel $X 2$

$\mathrm{X} 1$ = Suku bunga BI

X2 = Inflasi

$\varepsilon=$ standar error

Dari persamaan diatas, hasil yang dapat dijelaskan adalah sebagai berikut $Y=96,556366$ yang artinya bahwa ada pengaruh posif antara suku bunga dan inflasi terhadap kinerja keuangan bank syariah, tanda pada hasil $Y$ bila $Y$ negatif maka tidak ada hubungan antara variabel suku bunga dan inflasi terhadap kinerja keuangan bank syariah, sedangkan apabila hasil $Y$ nya positif maka menunjukkan ada pengaruh antara variabel suku bunga dan inflasi terhadap kinerja keuangan bank Syariah. Jadi dapat disimpulkan bahwa tanda pada hasil $Y$ adalah positif maka kenaikan tingkat suku bunga $\mathrm{BI}$ dan inflasi akan mempengaruhi juga pada hasil kinerja keuangan bank jatim syari'ah, apabila suku bunga BI dan inflasi naik maka kinerja keuangan bank jatim syari'ah juga akan naik, namun sebaliknya jika suku bunga BI dan inflasi turun maka kinerja keuangan bank jatim juga akan ikut turun. ${ }^{22}$

\section{Tabel 2.}

\section{Analisis Suku Bunga BI Dan Inflasi Terhadap Kinerja Keuangan Bank Syari'ah Dilihat Dari Output ANOVA Sig}

Output anova sig adalah hasil analisis regresi linier berganda dimana terdapat kolom anova yang mana kita menilai dari nilai sigma atau sig

\begin{tabular}{|r|r|r|l|l|l|}
\hline \multicolumn{7}{|c|}{ ANOVA $^{\text {b }}$} \\
\hline $1 \quad$ Rodel & $\begin{array}{c}\text { Sum of } \\
\text { Squares }\end{array}$ & Df & $\begin{array}{c}\text { Mean } \\
\text { Square }\end{array}$ & F & Sig. \\
\hline $\mathrm{n}$ & 147.582 & 2 & 73.791 & 4.395 & $.023^{\mathrm{a}}$ \\
Residual & 419.731 & 25 & 16.789 & & \\
Total & 567.313 & 27 & & & \\
\hline
\end{tabular}

a. Predictors: (Constant), Inflasi (X2), Suku bunga

(X1)

b. Dependent Variable: Kinerja keuangan bank $(\mathrm{Y})$

${ }^{22}$.Kadir, Statistika Terapan (Jakarta:Pustaka Jakarta, 2009), 196 
HO : Model persamaan regresi suku bunga BI dan Inflasi bepengaruh linier terhadap kinerja keuangan bank jatim syari'ah

H1 : Model persamaan regresi suku bunga BI dan inflasi bepengaruh linier terhadap kinerja keuangan bank syariah

Sig $=0,23 \rightarrow 0,23<5 \%$, maka $\mathrm{HO}$ ditolak,

Jadi Model persamaan regresi suku bunga BI dan Inflasi bepengaruh linier terhadap Jumlah kinerja keuangan bank syari'ah

Dapat disimpulkan bahwa apabila sigma dalam anova melebihi 5\% maka $\mathrm{HO}$ akan diterima yang artinya bahwa antara variabel suku bunga dan inflasi tidak ada pengaruh positif terhadap kinerja keuangan bank syari'ah, Namun apabila $\mathrm{H} 0$ ditolak jadi $\mathrm{H} 1$ yang diterima maka artinya bahwa variabel suku bunga $\mathrm{BI}$ dan inflasi ada pengaruh positif terhadap kinerja keuangan bank syariah.

Dari analisis diatas bisa dilihat bahwa sigma menunjukkan 0,23\% $<5 \%$ jadi $\mathrm{HO}$ ditolak karena hasil dari sigma kurang dari $5 \%$, yang artinya ada pengaruh positif antara variabel suku bunga BI dan inflasi terhadap kinrja keuangan bank syariah.

Tabel 3.

Analisis Suku Bunga BI Dan Inflasi Terhadap Kinerja Keuangan Bank Syari'ah Dilihat Dari Output Coefficients Sig

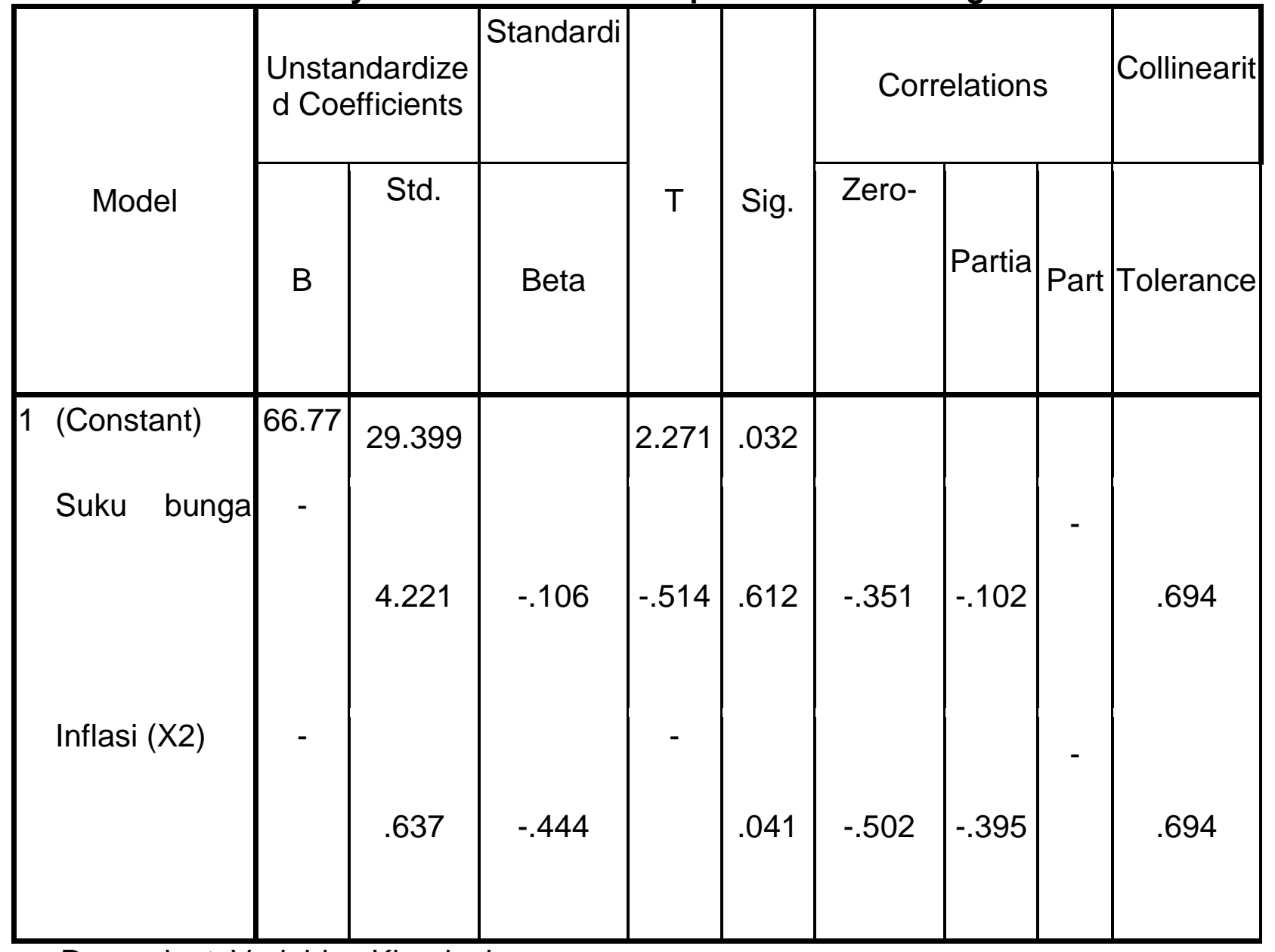

a. Dependent Variable: Kinerja keuangan bank (Y) 
1. Uji parater $\alpha$

$\mathrm{Ho}: \alpha=0$

$\mathrm{H} 1: \alpha \neq 0$

@ : $0,032 \neq 0$, maka H0 ditolak

Jadi dari uji parameter a dapat disimpulkan bahwa apabila nilai sigma sama dengan 0 maka maka $\mathrm{HO}$ akan diterima dan jika nilai sigma lebih dari 0 maka $\mathrm{HO}$ diterima, disini hasil dari uji parameter tersebut menunjukkan bahwa nilai sigma adalah 0,032 maka $\mathrm{H} 1$ yang diterima, yang artinya ada pengaruh antara variabel suku bunga dan inflasi terhadap kinerja keuangan bank syari'ah.

2. Ho: $\beta 1=0$ (tidak ada pengaruh suku bunga $\mathrm{BI}$ terhadap kinerja keuangan bank jatim syari'ah)

$\mathrm{H} 1: \beta 1 \neq 0$ (ada pengaruhsuku bunga $\mathrm{BI}$ terhadap kinerja keuangan bank jatim syari'ah)

$\beta 1(0,612) \neq 0$, maka $\mathrm{H} 0$ ditolak,

Dari uji parameter untuk suku bunga menunjukkan bahwa apabila nilai $\beta 1=0$ maka tidak ada pengaruh suku bunga $\beta I$ terhadap kinerja keuangan bank jatim. Namun untuk nilai $\beta 1$ menunjukkan bahwa nilai $\beta 1$ yaitu 0,612 jadi $\mathrm{H} 0$ ditolak, maka yang diterima $\mathrm{H} 1$ yang artinya bahwa ada pengaruh antara suku bunga $\mathrm{BI}$ terhadap kinerja keuangan bank jatim syari'ah

3. Ho: $\beta 2=0$ (tidak ada pengaruh inflasi terhadap kinerja keuangan bank jatim syari'ah)

$H 1: \beta 2 \neq 0$ (ada pengaruh inflasi terhadap kinerja keuangan bank syari'ah )

$\beta 2(0,041) \neq 0$, maka H0 ditolak

Untuk uji parameter inflasi menunjukkan bahwa apabila $\beta 2=0$ maka tidak ada pengaruh inflasi terhadap kinerja keuangan bank jatim syari'ah, namun untuk nilai $\beta 2$ menunjukkan bahwa $\beta 2=0,612$ yaitu lebih dari nol maka $\mathrm{H} 0$ ditolak, jadi dapat disimpulkan bahwa ada pengaruh antara inflasi terhadap kinerja keuangan bank syari'ah.

Dari ketiga uji parameter tersebut menunjukkan bahwa ada pangaruh positif antara suku bunga $\mathrm{BI}$ dan inflasi terhadap kinerja keuangan bank Syari'ah. ${ }^{23}$

Diagram 1.

${ }^{23}$ I Gusti Ngurah Agung, Statistika: Penerapan Model Linier univariat dan Multivariat (Jakarta:UI, 2003), 268 


\section{Analisa Suku Bunga BI Dan Inflasi Terhadap Kinerja Keuangan Bank Syari'ah Dilihat Dari Uji Normalitas (Output Normal P-P Plot)}

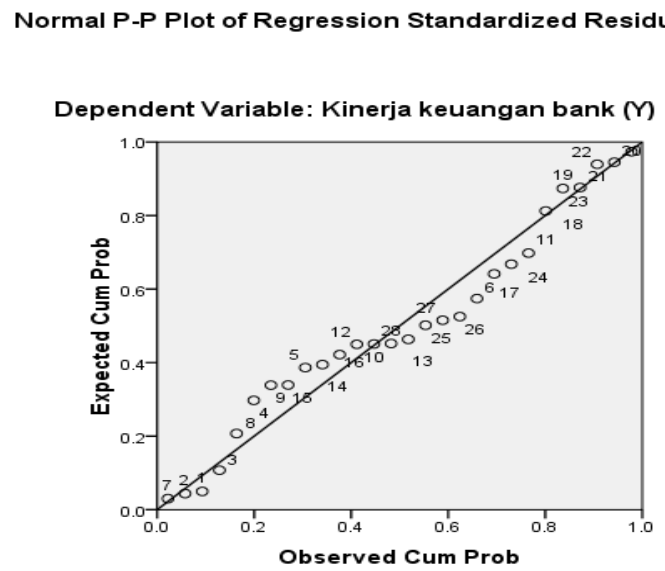

Dari uji normalitas menujukan bahwa data tersebut dikatan tidak noramal dimana data pada $p-p$ plot menyebar tidak mengikuti garis diagonal dan tidak mengikuti garis diagonal tersebut dan artinya bahwa antara variabel suku bunga $\mathrm{BI}$ dan inflasi berpengaruh positif terhadap kinerja keuangan bank syari'ah. Disini uji normalitas dikatan normal apabila data menyebar mengikuti garis diagonal dan mengikuti arah garis diagonal.

Diagram 2.

\section{Analisis suku bunga BI dan inflasi terhadap kinerja keuangan bank syari'ah dilihat dari uji heterokedastisitas (Scatterplot)}

Scatterplot

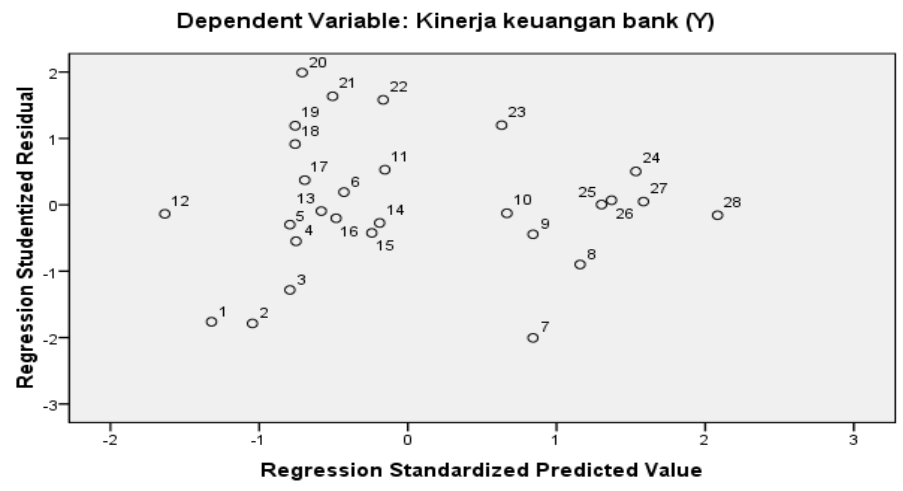

Dalam uji heterokedastisitas dikatan terjadi heterokedastisitas apabila data membetuk pola yang teratur dimana data tersebut bergelombang dan menyempit, sedang kan gambar diatas menunjukkan pola yang tidak beraturan (tidak bergelombang dan menyempit), jadi dalam uji heterokedastisitas tidak ada pangaruh yang signifikan antara variabel suku bunga $\mathrm{BI}$ dan inflasi terhadap kinerja keuangan bank syari'ah. ${ }^{24}$

Tabel 4.

\footnotetext{
${ }^{24}$ Ibid. 275
} 
Analisis suku bunga BI dan inflasi terhadap kinerja keuangan bank syari'ah dilihat dari uji Autokorelasi (Output Model Summary-Durbin

Watson)

Model Summary ${ }^{\mathrm{b}}$

\begin{tabular}{|c|c|c|c|c|c|}
\hline Model & $\mathrm{R}$ & $\begin{array}{c}\mathrm{R} \\
\text { Square }\end{array}$ & $\begin{array}{c}\text { Adjusted R } \\
\text { Square }\end{array}$ & $\begin{array}{c}\text { Std. Error of } \\
\text { the Estimate }\end{array}$ & $\begin{array}{c}\text { Durbin- } \\
\text { Watson }\end{array}$ \\
\hline 1 & $.510^{\mathrm{a}}$ & .260 & .201 & 4.09747 & .394 \\
\hline
\end{tabular}

a. Predictors: (Constant), Inflasi (X2), Suku bunga

(X1)

b. Dependent Variable: Kinerja keuangan bank $(\mathrm{Y})$

Dikatakan terjadi autokorelasi jika:

$\left(^{*}\right)$ Angka D-W $<-2$ : autokorelasi positif

(*) $-2<$ Angka D-W $>2$ : tidak ada autokorelasi

$\left({ }^{*}\right)$ Angka D-W $>2$ : autokorelasi negatif

Angka D-W :0,394, maka tidak ada autokorelasi

Diatas dijelaskan bahawa dikatakan terjadi autokorelasi jika angka durbin-watson kurang dari -2, maka terjadi auto korelasi positif, dan jika -2 kurang dari angka durbin Watson, dan kurang dari 2 maka tidak terjadi autokerelasi, sedangkan angka durbin Watson lebih dari 2 maka terjadi autokorelasi negatif, namun dari hasil summary durbin Watson menunjukkan kan angka 0,394 yaitu kurang dari -2 dan tidak melebihi 2, maka dapat dikatan bahwa tidak ada autokorelasi antara tingkat kenaikan suku bnga BI dan inflasi terhadap kinerja keuangan bank syari'ah.

\section{Kesimpulan}

Penelitian dapat disimpulkan bahwa:

1. Dari analisis spss tentang analisis suku bunga BI dan Inflasi terhadap kinerja keuangan bank syari'ah, dilihat dari output coefficients, output ANOVA sig, dan Coefficients sig menunjukkan bahwa ada pengaruh antara kenaikan tingkat suku bunga BI dan inflasi terhadap kinerja keuangan bank syari'ah.

2. Dari analisis spss dilihat dari uji normalitas (output normal p-pplot), uji heterokedastisitas (scatterplot), dan uji autokorelasi (ouput model summary durbin-watson), menunjukkan bahwa tidak ada pengaruh antara kenaikan tingkat suku bunga BI dan inflasi terhadap kinerja keuangan bank yari'ah.

3. Faktor yang mempengaruhi kenaikan tingkat suku bunga antara lain: kebutuhan dana, persaingan, kebijakan pemerintah, harga laba yang diinginkan, jangka waktu, kualitas jaminan, reputasi perusahaan, produk yang kompeitif, hubungan baik, dan jaminan pihak ke 3 .

4. Faktor yang menpengaruhi inflasi adalah jumlah uang beredar, produk domestic bruto, nilai tukar dan suku bunga.

\section{Daftar Pustaka}

Abdullah, Muhammad. Al-ribafi Nazar Al-Qanun Al Islam. Cairo: IAIB,tt.

Agung,I Gusti Ngurah, Statistika: Penerapan Model Linier Univariat dan Multivariat. Jakarta:UI, 2003

az-Zuhaily, Wahbah Usul Fiqh al-Islami. Beirut: Darul-Fikr, 1985. 
Chapra, M.Umer. Towards a Just Monetary System . London Leicester: Islamic Foundasion, 1985

CII ( Council of Islamic Ideology). Consolidated Recommendation on the Islamic Economic system. ( Islamadad: Council of Islamic Ideology, 1983

Harran, Sa'ad A.S. Islamic Finance Partnership Financing. Kuala Lumpur: Pelanduk Publikation, 1983

Huda, Nurul. Ekonomi Makro Islam:Pendekatan Teoritis. Jakarta: Kencana 2009

Ihram, Fahmi. Manajemen Perbankan: Konvensional dan Syariah. Jakarta:Mitra Wacana Media,2015

Kadir. Statistik Terapan.Jakarta:Pustaka Jakarta:2009

Mawdudi, Abu al-A'la. Prohibitionof Inters in Islam. Islamabad: Al-Islam, june, 1986

Fikr.n.d.1970

. Al-Hadarat al-Islamiyya. Al-Riba trans. Beirut: Dar al. Towards Understanding Islam the Qur'an ,Trans. (London Leicester:Islamic Foundasion, 1988.

Qutb, Sayyid. Fi zilal al-Qu'an. Tafsir Ayat al-Riba. Beirut: Dar al-Buhut al'Ilmiyya, 1961.

Raharjo, Dawam. The Question of Islamic Banking in Indosesia. Dalam Mohamed Aril (ed), Islamic Banking In Sout East Asia. Singapura:ISEAS, 1988

Sharif, .Muhammad. Sistem Ekonomi Islam: Prinsip Dasar. Jakarta: Kencana Prenada Media Group, 2012.

Shawq, Dunya. Taqallubat al-Quwwal al-Syira'iyya li al-Nuqud, Masir: Bunuq alIslaamiyyah, 1985

www.bi.go.id dan Fahmi Ihram, Manajemen Perbankan: Konvensional dan Syariah. Jakarta:Mitra Wacana Media, 2015

www.bi.go.id, http://www.bi.go.id/id/moneter/bi-rate/data/Default.

Zahra, Muhamad Abu. Bahuth fi al-Riba. Kuwait: Dar al-Buhuth al-IImiyya, 1970. 